\title{
Spatial distribution analysis of bovine fascioliasis cases recorded in an abattoir in the state of Santa Catarina, Brazil
}

\author{
Renata Barbosa da Fonseca e Albuquerque ${ }^{1^{*}}$ (i) Sandro Antonio Pereira $^{1}$ (D) \\ Saulo Nascimento de Melo $^{2}$ (iD Vinícius Silva Belo ${ }^{2}$ (iD \\ Mauro Maciel de Arruda ${ }^{3}$ (D) Diego Mazetto ${ }^{3}$ (D) Fabiano Borges Figueiredo ${ }^{4}$ (D)
}

\author{
${ }^{1}$ Fundação Oswaldo Cruz, 21040-360, Manguinhos, RJ, Brasil. E-mail: renatabfal@gmail.com."Corresponding author. \\ ${ }^{2}$ Universidade Federal de São João del Rei (UFSJ), Divinópolis, MG, Brasil. \\ ${ }^{3}$ Universidade Barriga Verde (UNIBAVE), Orleans, SC, Brasil. \\ ${ }^{4}$ Instituto Carlos Chagas - Fiocruz, Curitiba, PR, Brasil.
}

\begin{abstract}
Fascioliasis is a zoonosis of global distribution caused by the parasitic trematode Fasciola spp. Infection in humans can occur in areas endemic for animal fascioliasis, suggesting the need for studies on this parasitosis and its determinants. This exploratory study aimed to analyze the spatial distribution of bovine fascioliasis in the state of Santa Catarina, Brazil, based on cases notified between 2015 and 2017 in a state abattoir, located in the municipality of Orleans, and to associate disease occurrence with altitude, temperature, and rainfall. The research was conducted at Centro Universitário Barriga Verde (UNIBAVE)/Orleans, SC and Fundação Oswaldo Cruz/Rio de Janeiro, RJ. During the study period, the abattoir received animals from 58 municipalities in that state. Of the animals slaughtered in that period, $10,81 \%$ were infected with Fasciola hepatica. Presence of bovine fascioliasis infection was identified in the South and Southeast regions of the state, with higher prevalence rates in the latter. There was an association between low altitudes and higher occurrence of cases in the municipalities assessed. In addition, prevalence of bovine fascioliasis was higher in municipalities with high temperatures and low rainfall. Therefore, these results should be considered for planning disease control measures in the South and Southeast regions of the state of Santa Catarina. Key words: Fasciola hepatica, georeferencing, cattle, zoonosis.
\end{abstract}

Análise da distribuição espacial dos casos de fasciolose bovina registrados em abatedouro de Santa Catarina, Brasil

\begin{abstract}
RESUMO: A fasciolose é uma zoonose de distribuição global causada pelo parasita Fasciola spp. Infecções em humanos podem ocorrer em áreas endêmicas para fasciolose animal, sugerindo a necessidade de estudos sobre essa parasitose e seus determinantes. O presente estudo exploratório teve como objetivo analisar a distribuição espacial da fasciolose bovina, no estado de Santa Catarina, Brasil, a partir de casos notificados entre 2015 e 2017 no abatedouro frigorifico estadual, localizado em Orleans, SC, e associar a ocorrência da doença a altitude, temperatura e precipitação. A pesquisa foi conduzida na Universidade Barriga Verde em Orleans, SC e na Fundação Oswaldo Cruz no Rio de Janeiro, RJ. No período de análise o matadouro recebeu animais de 58 municípios do estado de Santa Catarina. Dos animais abatidos nesse periodo, 10,81\% estavam infectados por Fasciola hepatica. A presença da infecção por fasciolose foi encontrada no Sul no território estudado, com maiores prevalências no Sudeste do estado. Houve uma associação entre baixas altitudes e maior ocorrência de fasciolose nos municípios. A prevalência de fasciolose bovina foi também maior em municípios com altas temperaturas e com baixa pluviosidade. Sendo assim, esses resultados devem ser levados em consideração para o planejamento de medidas de controle da doença no Sul de Santa Catarina. Palavras - chave: Fasciola hepática, georreferenciamento, bovinos, zoonose.
\end{abstract}

\section{INTRODUCTION}

Fascioliasis is a zoonotic disease caused by the liver fluke Fasciola spp. and is considered the helminthiasis of highest prevalence worldwide (FORERO et al., 2016). Disease cycle depends on environmental conditions such as high rainfall and temperature, as well as on the presence of intermediate hosts, namely, Lymnaea snails (MAS-COMA et al., 2005; CHARLIER et al., 2011; DUTRA et al., 2010; BENNEMA et al., 2014). Several mammals, including humans, swine, equines, caprine, camelids, lagomorphs, cervids, and mainly sheep and bovines, can be definitive hosts for $F$. hepatica (MULLER, 2002). Although, fascioliasis is classified as a zoonosis, its occurrence in humans is rare and its greatest relevance is due to the worldwide economic losses it causes in livestock production, estimated at 
over USD 2 billion/year, with more than 600 million animals infected (FORERO et al., 2016). In Brazil, the number of discarded livers and the weight reduction of animal carcasses result in an economic loss of approximately USD 210 million/year. The states of Rio Grande do Sul and Santa Catarina present the first and second greatest losses, USD 147.4 and 24.6 million/year, respectively (MOLENTO et al., 2018; SILVA et al., 2020).

In Brazil, the highest prevalence of bovine fascioliasis occurs in the South and Southeast regions, especially in the state of Rio Grande do Sul, followed by the states of Santa Catarina, São Paulo, and Rio de Janeiro (OLIVEIRA \& ESPOSITO, 2009). A similar study conducted by SILVA et al. (2020) analyzed data from a federal abattoir in the state of Santa Catarina from 2004 to 2008 and in 2010, and reported that $8,8 \%$ of livers were condemned as a consequence of $F$. hepatica infection. Infection in humans can occur in areas endemic for animal fascioliasis depending on their eating habits, e.g., unwashed watercress (ROBINSON \& DALTON, 2009), suggesting the need for epidemiological studies to understand disease occurrence and transmission dynamics among animals, evaluate its incidence, and locate its enzootic foci.

Sanitary inspections in abattoirs are an opportunity to identify these factors (MACIEL \& PAIM, 1966; FORERO et al., 2016). The use of geospatial tools, in turn, enables detection of areas with potential risk of infection for both animals and humans and, coupled with adequate surveillance, can guide prevention and control strategies.

The present study investigated the prevalence of bovine fascioliasis in the cattle shipping coverage area of an abattoir located in the municipality of Orleans, state of Santa Catarina, Brazil, between 2015 and 2017 and to describe the association of disease occurrence with altitude, temperature and rainfall data. The Orleans abattoir received bovines and swine from the whole state of Santa Catarina and sells the slaughtered animals statewide.

\section{MATERIALS AND METHODS}

This is a spatial study based on the survey of cases of bovine fascioliasis diagnosed in a state slaughterhouse in Orleans, a predominantly rural municipality located in the South region of the state of Santa Catarina. The study gathered data from the slaughterhouse records between July 2015 and December 2017. The data were collected by municipality of the state.
The state of Santa Catarina is located in the South region of Brazil, occupies an area of 95.733 $\mathrm{km}^{2}$, and has great landscape variations. The North region of the state is marked by valleys and rivers with altitudes $<200 \mathrm{~m}$. In the South region, there is a mountain ridge that rises over 1000 m.a.s.l. Rivers formed in these higher altitudes flow towards the coast, which occupies the East region of the state. Temperature varies according to altitude and proximity to the shore (BRASIL, 2004).

Based on the animal entry and carcass condemnation forms obtained from the State Sanitary Inspection Service (SIE-DEINP) in the abattoir, the origins of the slaughtered animals and the fascioliasis diagnoses were analyzed. Fascioliasis is detected during the slaughter routine: in the inspection line, the liver of each animal is sectioned and macroscopically examined, when adult flukes are present, they can be easily observed in the bile ducts or in parenchymal calcification (JENSEN \& MACKEY, 1965).

The environmental variables suggestive to determine the spatial distribution of bovine fascioliasis in the state are altitude, average annual temperature, and average annual rainfall by municipality. There are other factors that may influence fascioliasis occurrence, such as cattle trade and transport between regions, introduction of infected animals in non-endemic areas, and extensive management system, where animals are fed in pastures (GUIMARÃES, 2011).

The environmental data were obtained from the websites of the Rural Extension and Agribusiness Research Company of Santa Catarina (EPAGRI/CIRAM) (available at $<$ http://ciram.epagri. sc.gov.br/index.php?option=com_content\&view=art icle\&id=98\&Itemid=198>; accessed on October 26, 2018). The data for the study period (July 2015 to December 2017) were collected from these websites by municipality. For the analysis, the average temperature and rainfall for the study period were calculated by municipality.

The Shapiro-Wilk test (1965) was applied to analyze the distribution of values for each of the quantitative variables studied. In view of the asymmetric distribution of the data, the Spearman's rank correlation coefficient (ZAR, 2014) was used to test the association between the prevalence of fascioliasis in the municipalities and the variables temperature, altitude, and rainfall. The data were processed in the $R$ Studio software using the 'plotly' (SIEVERT, 2018) and 'magrittr' (BACHE \&WICKHAM, 2014) packages. Prevalence of fascioliasis by municipality was smoothed using 
the local Empirical Bayes method (ASSUNÇÃO et al., 2005).

Because some municipalities sent few animals for slaughter, the prevalence of fascioliasis by municipality needed to be smoothed. The smoothing prevalence weighed the municipalities according to the number of animals sent for slaughter, since some municipalities sent more animals than others. The local Bayes rates were calculated with correction of the multiplicative rate equal to one and the distances between the centroids of the municipalities were calculated using Euclidean distance. The smoothing prevalence was used in all spatial analyses and there was no minimum number of infected animals.

In order to analyze the distribution of fascioliasis in the state of Santa Catarina, two maps were constructed (Figures 1 and 2), presenting the prevalence of fascioliasis by municipality and the local Moran's index (Moran's I) (Local Indicator of Spatial Association - LISA) to identify regions with disease clusters. The Moran LISA test categorizes high and low prevalence according to the prevalence in neighboring municipalities and their statistical significance. The municipalities were classified according to their category and statistical significance on the local Moran map as follows: municipalities with high prevalence of fascioliasis whose neighboring municipalities also presented high prevalence of the disease were displayed in red $(\mathrm{Q} 1+/+)$; municipalities with low prevalence of fascioliasis whose neighboring municipalities also presented low prevalence of the disease were displayed in blue (Q2-/-); municipalities with high prevalence of fascioliasis whose neighboring municipalities presented low prevalence of the disease were displayed in green (Q3+/-); municipalities with low prevalence of fascioliasis whose neighboring municipalities presented high prevalence of the disease were displayed in yellow (Q4-/+). The municipalities displayed in light gray ("not significant") presented no spatial correlation for prevalence of fascioliasis and those displayed in dark gray ("neighborless") had no neighboring municipalities in the cattle shipping coverage area of the abattoir.

The GeoDa, Terraview 4.2.2 and QGIS 2.18.24 software packages were used to construct the maps and process the spatial statistical analysis taking the map of the state of Santa Catarina as a cartographic basis.

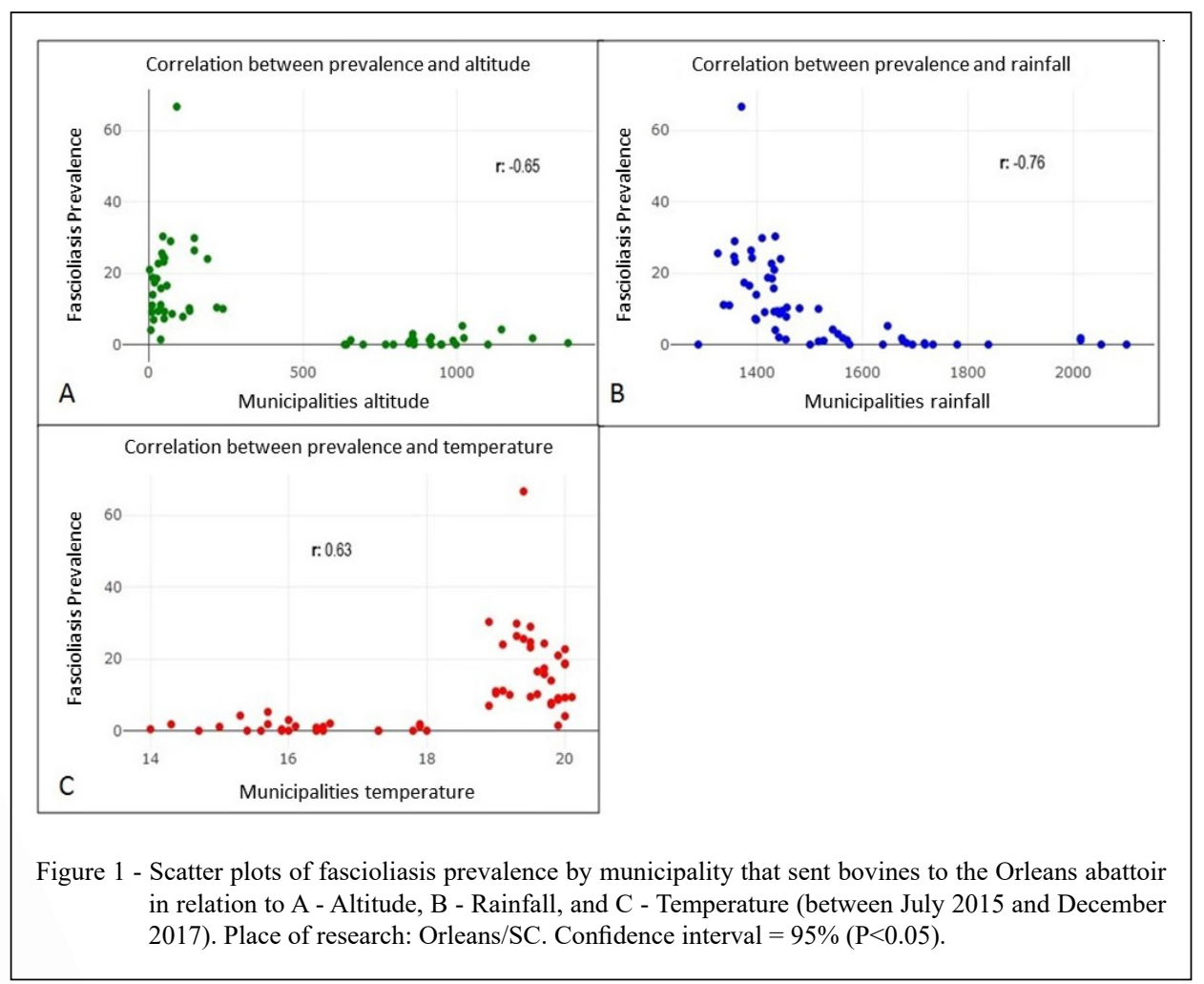

Ciência Rural, v.52, n.3, 2022. 


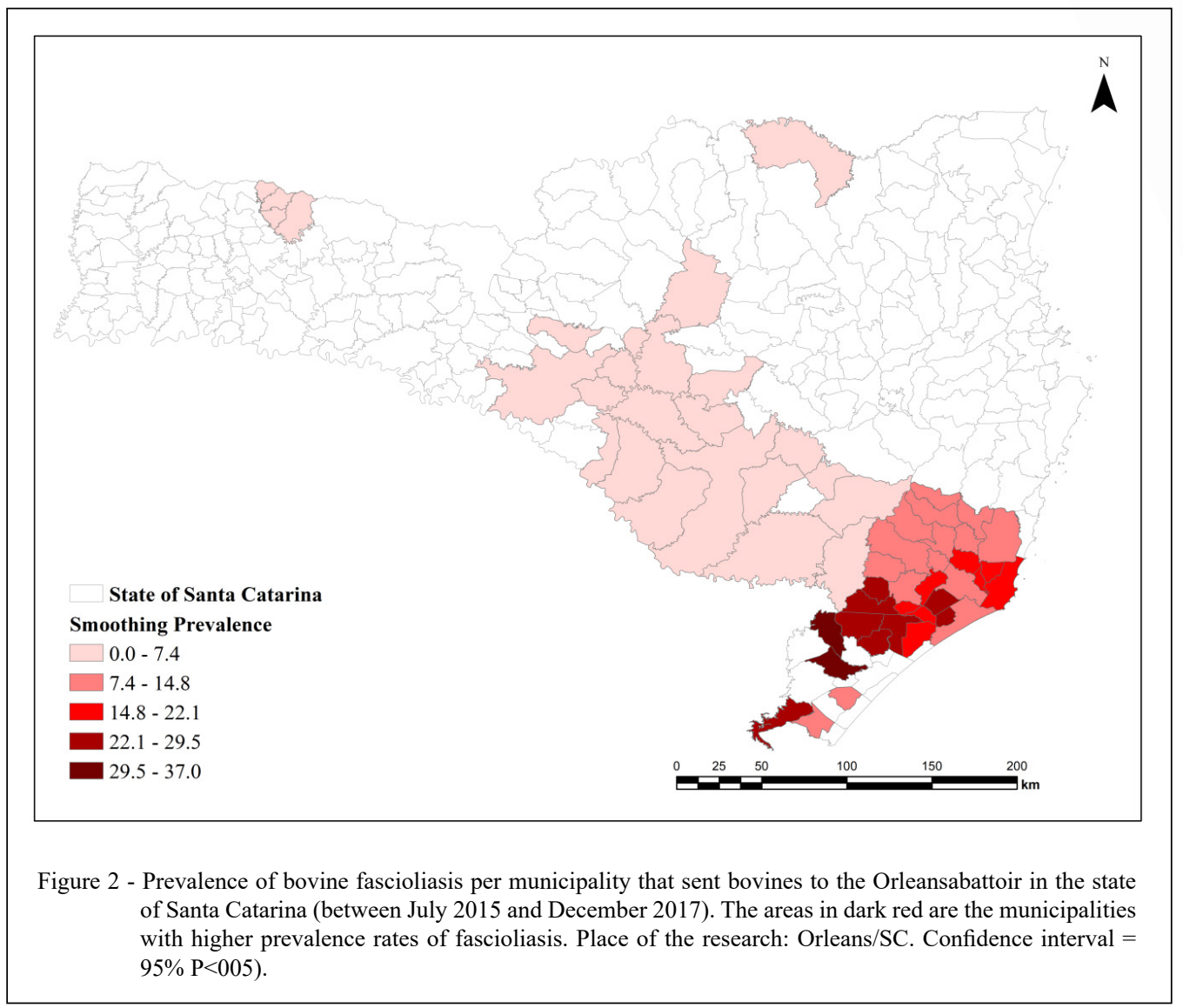

\section{RESULTS}

During the study period, the abattoir received animals from 58 municipalities in the state of Santa Catarina. Of the 24.961 animals slaughtered, 2.699 (10,81\%, confidence interval: 10,43-11,20\%) were infected with $F$. hepatica (Table. 1).

Figure 1 shows the scatter plots of the analyzed correlations. In the scatter plots, prevalence of fascioliasis was higher in municipalities with high average temperatures, low rainfall, and low altitudes. The identified $R$ value $(0,6-0,7)$ is considered moderate (MUKAKA, 2012) and all the $P$ values were $<0,05$.

Only $11(18,96 \%)$ of the 58 municipalities that sent cattle to the abattoir had no animals positive for $F$. hepatica. The municipality of São Ludgero, located in the Eastern border of Orleans,

Table 1 - Number of cattle received and number of cattle positive for $F$. hepatica, per year, in the investigated slaughterhouse in OrleansSC (2015-2017). ${ }^{*}$ The carcass condemnation forms were provided as of July 2015, thus data for this year are incomplete. Confidence interval $=95 \%(\mathrm{P}<0.05)$.

\begin{tabular}{lccc}
\hline Year & Number of cattle received & Number of cattle positive for $F$. Hepatica & Prevalence (Confidence Interval) \\
\hline $2015^{*}$ & 5907 & 568 & $9.62 \%(8.88-10.40)$ \\
2016 & 9533 & 844 & $8.85 \%(8.29-9.44)$ \\
2017 & 9521 & 1287 & $13.52 \%(12.84-14.22)$ \\
TOTAL & 24961 & 2699 & $10.81 \%(10.43-11.20)$ \\
\hline
\end{tabular}


sent the largest number of animals to the abattoir $(3630 ; 14,54 \%)$ and presented the largest number of infected cattle (333; 9,17\%, confidence interval: 8,25 - 10,16\%), followed by Orleans, which sent 3010 animals $(12,06 \%)$ for slaughter, with $284(9,43 \%$, confidence interval: $8,41-10,54 \%$ ) infected cattle.

The spatial distribution of smoothed prevalence values in the studied municipalities showed that specific regions of the state presented higher prevalence rates (Figure 2). The municipalities of state that sent bovines to the abattoir during the study period were grouped according to the smoothed prevalence interval for bovine fascioliasis they belonged (Table 2).

The local Moran's I (Figure 3) shows the priority attention areas, located to the North of Orleans, in the Southeast region of the state, the municipalities displayed in red $(\mathrm{Q} 1+/+)$, which presented high prevalence of fascioliasis and whose neighboring municipalities also presented high prevalence of the disease. The following municipalities were included in this category: Siderópolis, Nova Veneza, Criciúma, Forquilinha, Turvo, Morro da Fumaça, and Jaguaruna. Municipalities displayed in white (Figures 2 and 3) did not send cattle to the state abattoir in Orleans.

\section{DISCUSSION}

The associations established between occurrence of bovine fascioliasis and the temperature, altitude and rainfall variables are valid regardless of the representativeness of the sample because the abattoir receives animals from various municipalities of the state; therefore, the data presented the variability needed to conduct valid statistical analysis, thus the study presents external validity and can be applied to similar epidemiological contexts. Abattoir data are not primarily collected for research purposes, creating several potential methodological flaws in their use (CAROL, et al. 2017).

In the system of breeding and preparing cattle for slaughter, the breeding, rebreeding, and fattening of animals can be carried out in different locations and by different producers; however, in abattoirs statistics, animal origin records may inform only the place of final shipment. Therefore, these records should be interpreted with caution when used as source of information in sites enzootic for a given disease. In addition to the shipment location to the abattoir, it is necessary to know the origin of the animals and the locations where they were raised and fattened (MACIEL \& PAIM, 1966). Abattoirs also present imperfect sensitivity and specificity of infection detection, because there is an error window in the case of very early-stage infections (MAZERI, et al. 2016). Despite these limitations, the study of prevalence of fascioliasis based on abattoir records has some advantages, as it easily allows rapid verification of disease occurrence at low costs. Although, the locations where the animals were infected cannot be accurately determined, the results revealed the occurrence of bovine fascioliasis in the study area. Moreover, the locations can provide information on infection severity according to the degree of damage, be a resource for researchers to estimate prevalence of infection or disease in farm animal populations, and assist with identifying priorities in animal health policy (CAROL, et al. 2017; MAZERI, et al. 2016).

Results of the present study suggested a possible association between low altitudes and higher occurrence of fascioliasis in herds. A study conducted in the South region of Brazil reported

Table 2 - Smoothed Prevalence Interval for F. hepatica and the municipalities of the state of Santa Catarina that sent animals to the slaughterhouse in Orleans between July 2015 and December 2017. Confidence interval $=95 \%(\mathrm{P}<0.05)$.

\begin{tabular}{lc}
\hline $\begin{array}{l}\text { Smoothed Prevalence } \\
\text { Interval (\%) }\end{array}$ & Municipalities \\
\hline $29.5-37.0$ & Morro Grande; Turvo \\
\hline $22.1-29.5$ & Praia Grande; Nova Veneza; Siderópolis; Trevisto; Criciuma; Forquilhinha; Treze de Maio; Sangão \\
\hline $14.8-22.1$ & Cocal do Sul; Içara; Morro da Fumaça; Pedras Grandes; Gravatal; Capivari de Baixo; Laguna \\
$7.4-14.8$ & $\begin{array}{c}\text { Orleans; São Ludgero; Urussanga; Lauro Muller; Braço do Norte; Grão Para; Rio Fortuna; Santa Rosa } \\
\text { de Lima; São Martinho; Imaruí; Armazem; Tubarão; Jaguaruna; São João do Sul; Sombrio do Sul }\end{array}$ \\
& $\begin{array}{c}\text { Bom Jardim da Serra; Urubici; São Joaquim; Rio Rufino; Bocaina do Sul; Painel; Lages; Capão Alto; } \\
\text { Vargem; Campos Novos; Correia Pinto; São José do Cerrito; Campo Belo do Sul; Ponte Alta; } \\
\text { Curitibanos; Brunópolis; Tangará; Frei Rogério; Santa Cecília; Cerro Negro; Mafra; Jupiá; Galvão; } \\
\text { Coronel Martins; São Domingos }\end{array}$ \\
\hline
\end{tabular}

Ciência Rural, v.52, n.3, 2022. 


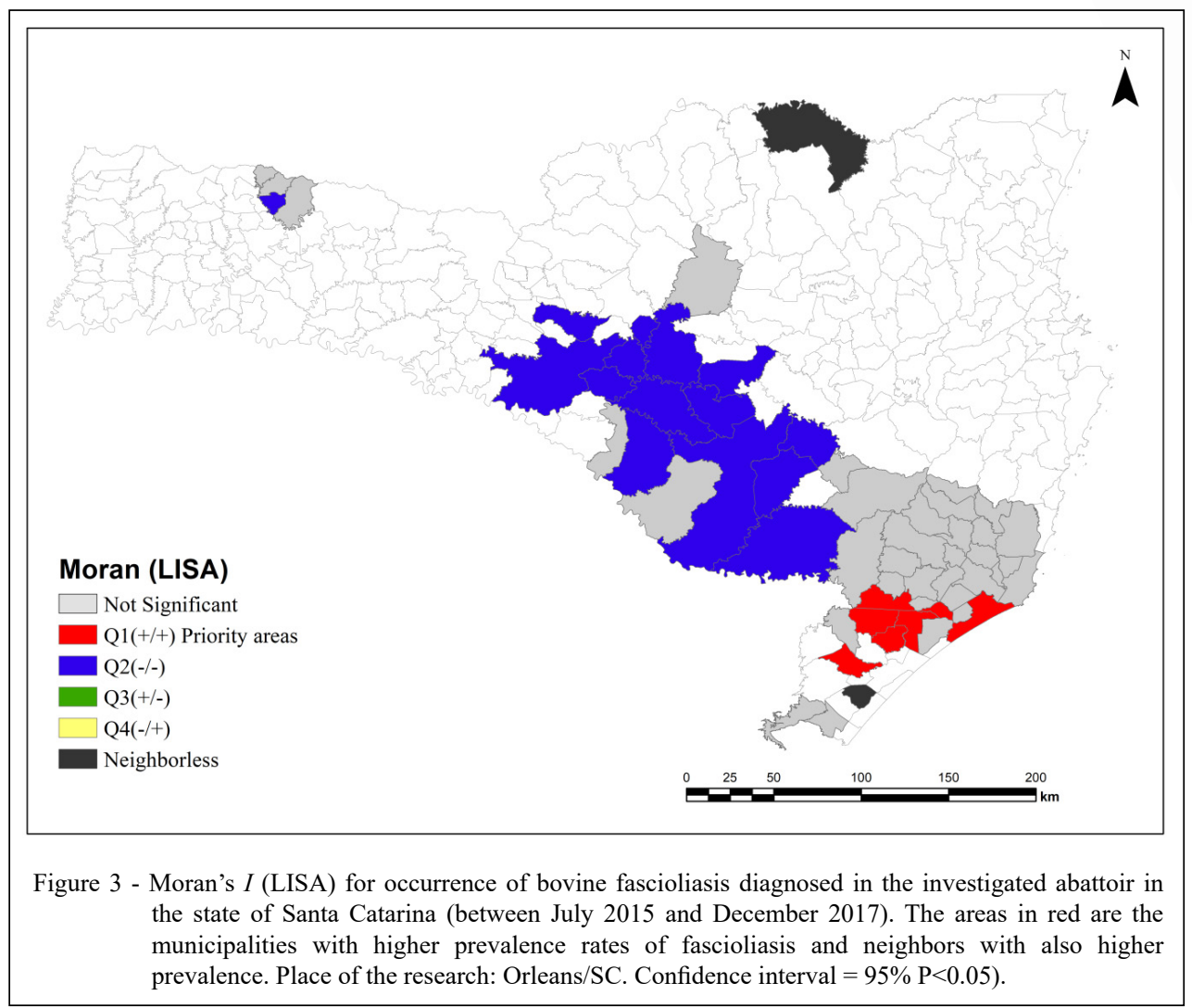

that municipalities located in lower areas (up to 154 m.a.s.l.) presented a higher risk of infection by $F$. hepatica (DUTRA et al., 2010). This can be justified by the fact that higher areas present higher rates of soil moisture evaporation, lower temperatures, and relief with greater slopes that hinders water accumulation and floods and; consequently, the survival of intermediate hosts (DUTRA et al., 2010). SILVA et al. (2020) reported similar results in a study that analyzed data from 2004 to 2008 and of 2010. Those authors observed higher prevalence of fascioliasis in lower areas of the state and co-related it with higher temperatures. MAS-COMA et al. (2001) reported that, in locations of high altitudes and with presence of the parasite, other factors such as high temperature and rainfall foster disease dispersion in herds.

In the present study, prevalence of fascioliasis was higher in municipalities with higher average temperatures. In the state of Santa Catarina, temperature is conditioned by altitude, action of polar masses, latitude, and continentality. The highest annual average temperature occurs on the North coast, $21,8^{\circ} \mathrm{C}$ (2 m.a.s.1.), whereas the lowest average temperature occurs in the South region, in the municipality of São Joaquim, $13{ }^{\circ} \mathrm{C}$ (1400 m.a.s.1.) (BRASIL, 2004). High temperatures are important for the continuation of $F$. hepatica cycle in the external environment. When the eggs of this trematode reach the environment, they need temperatures between 15 and $25^{\circ} \mathrm{C}$ to continue their development. Cercariae inside the intermediate host develop in seven weeks at temperatures between 20 and $25^{\circ} \mathrm{C}$, and it takes longer for them to develop at lower temperatures. They leave the snail at temperatures between 9 and $26{ }^{\circ} \mathrm{C}$ (MASCOMA, 2004). Lymnaeid snails can survive in dry mud during periods of drought and resist low temperatures (OLIVEIRA \& ESPÓSITO, 2009).

In the study sample, prevalence of fascioliasis was higher in municipalities with low rainfall. This negative association could be explained by the fact that the municipalities with greater rainfall are located at higher altitudes and present lower temperatures. The state of Santa Catarina presents high rainfall with even distribution throughout the year and an undefined dry season. Average annual rainfall ranges from 1219 to $2373 \mathrm{~mm}$ (BRASIL, 2004). A similar conclusion was reached by SILVA et al. (2020), who demonstrated that accumulated 
rainfall in the state was above the threshold to threaten the prevalence of fasciolosis, and no correlation to this risk factor could be established through analysis of the data.

Soil moisture can also be important in the distribution and occurrence of the $F$. hepatica cycle. Regions with alluvial and poorly drained soils are more associated with fascioliasis than those with deep, welldrained soils (SELEMETAS et al., 2015). Overall, there is no water deficiency in the soils of the state of Santa Catarina, and excess water levels are adequate (BRASIL, 2004). Mollusks such as Lymnaea columella and $L$. viatrix can be reported in soils with accumulated water, irrigation channels with little water, temporary or permanent water bodies, small streams, mud, and swamps (OLIVEIRA \& ESPÓSITO, 2009). These mollusks have the potential to quickly multiply and colonize temporary water collections formed by rain and hibernate during the dry periods (MAS-COMA, 2004).

The municipalities with the highest prevalence rates of fascioliasis are those located in the South and Southeast regions of the state. These municipalities occupy lower areas with higher temperatures. The study conducted by SILVA et al. (2020) did not present significant data on the Southeast region of the state and reached the conclusion that the coastal region had the highest temperatures and that $F$. hepatica was present in most of the Northern coast extension. The present study and SILVA et al. (2020) can be complementary, and they highlight that the whole coastal extension and the low areas of the state can be endemic for bovine fascioliasis.

The municipalities of Turvo, Nova Veneza, Siderópolis, Criciuma, and Forquilhinha presented the highest prevalence rates of fascioliasis $(>22,1 \%)$ and neighboring municipalities with high prevalence of the disease. These municipalities are the most critical, and local authorities, along with farmers, should implement control measures, such as testing recently bought animals before including them in the herds, limiting pasture feeding and natural water sources, and implementing a diagnosis protocol. Trading of infected animals can be occurring between these municipalities.

Municipalities with prevalence rates $>7,4 \%$ (Orleans, São Ludgero, Urussanga, Pedras Grandes, Laguna, and Capivari de Baixo) should also implement an animal diagnosis program and control measures.

The municipalities at the West border of Orleans (São Joaquim, Urubici, and Bom Jardim da Serra) are the ones with the lowest prevalence rates of fascioliasis $(<7,4 \%)$. This area presents high altitude and can reach negative temperatures. Although, these municipalities are neighbors with others that present high prevalence rates of fasciolosis (Orleans, Lauro
Muller, and Grão Para), the disease does not find natural conditions to perpetuate in these locations.

\section{CONCLUSION}

Distribution of cases of bovine fascioliasis was identified in the South and Southeast regions of the state of Santa Catarina, with higher prevalence rates observed in the latter. The highest prevalence of this disease was associated with areas of lower altitudes and higher temperatures; therefore, these results should be considered for planning control measures and a treatment protocol.

Climate change is likely to contribute to the adaptability of this parasitic infection with the increase of temperatures, thus it is important to epidemiologically monitor disease progression in locations where its prevalence is low.

\section{ACKNOWLEDGEMENTS}

The authors are grateful to Fundação Oswaldo Cruz - Instituto Nacional de Infectologia, to the professionals at the Centro Universitário Barriga Verde (UNIBAVE) and to Fundação de Amparo à Pesquisa e Inovação do Estado de Santa Catarina (FAPESC) for their partnership. This study was financed in part by the Coordenação de Aperfeiçoamento de Pessoal de Nível Superior - Brasil (CAPES) - Finance Code 001.

\section{ETHICS COMMITTEE}

This study was approved by the Research Ethics Committee on Animal Use of UNIBAVE under protocol no. 2.510.375.

\section{AUTHORS CONTRIBUITION}

All authors contributed equally to the design and writing of the manuscript. All authors critically reviewed the manuscript and approved its final version.

\section{CONFLICTS OF INTEREST STATEMENT}

The authors certify that they have no affiliations with or involvement in any organization or entity with any financial or non-financial interest in the subject matter or materials discussed in this manuscript.

\section{REFERENCES}

ASSUNÇÃO, R. M. et al. Empirical Bayes estimation of demographic schedules or small areas. Demography. 42. p.537-558, 2005. Available from: <https://pubmed.ncbi.nlm. nih.gov/16235612/>. Accessed: Oct. 20, 2020. doi: 10.1353/ dem.2005.0022.

BACHE, S. M., WICKHAM, H. 2014. Plotly for R. Retrieved from: $<$ https://CRAN.R-project.org/package=-magrittr>. Accessed: Oct. 20, 2020. 
BENNEMA, S. C. et al. Fasciola hepatica in bovines in Brazil: data availability and spatial distribution. Rev. Inst. Med. Trop. Sao Paulo, v.56, n.1. p.35-41, 2014.. Available from: $<$ https://www. scielo.br/j/rimtsp/a/YRrRKmDxWrN5yHXSp5fvP6D/?lang=en> Accessed: Oct. 26, 2018. doi: 10.1590/S0036-46652014000100005

BRASIL. Ministério da Agricultura e do Abastecimento. Empresa Brasileira de Pesquisa Agropecuária. Boletim de Pesquisa e Desenvolvimento: Solos do Estado de Santa Catarina. n.46. p.745, 2004. Available from: <https://www.infoteca.cnptia. embrapa.br/handle/doc/964417>. Accessed: Jun. 15, 2020.

CARROLL, R. I. et al. A protocol to identify and minimise selection and information bias in abattoir surveys estimating prevalence, using Fasciola hepatica as an example. Prev Vet Med. v.144, p.57-65, 2017. Available from: $<$ https://pubmed.ncbi.nlm.nih.gov/28716204/>. Accessed: Mar. 15, 2021. doi: 10.1016/j.prevetmed.2017.05.019.

CHARLIER, J. et al.. Towards assessing fine-scale indicators for the spatial transmission risk of Fasciola hepatica in cattle. Geospat Health. v.5. p.239-245, 2011. Available from: <https://www. geospatialhealth.net/index.php/gh/article/view/176>. Accessed: Mar. 15, 2018. doi: 10.4081/gh.2011.176.

DUTRA, L. H. et al. Mapping risk of bovine fasciolosis in the south of Brazil using geographic information systems. Vet Parasitol. v.169. p.7681, 2010. Available from: <https://pubmed.ncbi.nlm.nih.gov/20071083/>. Accessed: Mar. 15, 2018. doi: 10.1016/j.vetpar.2009.12.015.

EPAGRI - Rural Extension and Agribusiness Research Company of Santa Catarina \& CIRAM - Santa Catarina Environmental Resources and Hydrometeorology Information Center. Available from: <http://ciram.epagri.sc.gov.br/index.php?option=com_conten t\&view $=$ article\&id=98\&Itemid=198>. Accessed: Jun. 26, 2020 .

FORERO, J. C. G. et al. Prevalencia de Fasciola hepatica en Bovinos Sacrificados en la Planta de Beneficio del Municipio de Une, Cundinamarca, Colombia. Rev Inv Vet Perú, v.27, n.4. p.751-757, 2016. Available from: <http://www.scielo.org.pe/ scielo.php?script=sci_arttext\&pid=S1609-91172016000400014>. Accessed: Mar. 15, 2018. doi: 10.15381/rivep.v27i4.12572.

GUIMARÃES,M.P.Fasciolahepatica.In:NEVES,D.P.(Org).Parasitologia Humana. 12. ed. São Paulo: Editora Atheneu. p.241 - 244,2011.

JENSEN, R., MACKEY, D.R. Diseases Caused By Metazoan Parasites: Liver Fluke Disease. In: Deseases of Feedlot Cattle. Philadelphia: Lea \& Febiger, 1965. p.169 - 176.

MACIEL, G. A., PAIM, G. V. Os dados nosogeográficos obtidos através do matadouro e a sua importância para a saúde pública. Arq. Fac. Hig. v.20 p.241-249, 1966. Available from: <https:// www.revistas.usp.br/afhsp/issue/download/6578/131>. Accessed: Mar. 15, 2018. doi: 10.11606/issn.2358-792X.v20i2p241-249.

MAS-COMA, S. et al. Fasciola hepatica and lymnaeid snails occurring at very high altitude in South America. Parasitology, n.123.p.115-127,2001. Available from: $<$ https://www.researchgate. net/publication/11589119 Fasciola hepatica and lymnaeld snails occurring at very high altitude in South America $>$. Accessed: Mar. 15, 2018. doi: 10.1017/S0031182001008034.

MAS-COMA, S. Human fascioliasis: epidemiological patterns in human endemic areas of South America, Africa and Asia. Southeast Asian J Trop Med Public Health 35 (Suppl 1). p.1-11, 2004. Available from: <https://pubmed.ncbi.nlm.nih.gov/16153314/>. Accessed on March 15, 2018. doi: 10.1079/joh2005296.
MAS-COMA, S. et al.. Fascioliasis and other plant-borne trematode zoonoses. Int J Parasitol. v.35. p.1255-1278, 2005. Available from: <https://pubmed.ncbi.nlm.nih.gov/16150452/>. Accessed: Mar. 15, 2018. doi: 10.1016/j.ijpara.2005.05.010.

MAZERI, S. et al.. Evaluation of the performance of five Diagnostic Tests for Fasciola hepatica Infection in Naturally Infected Cattle Using a Bayesian No Gold Standard Approach. PloS one, v.11, n.8, 2016. Available from: <https://journals.plos.org/plosone/ article? id=10.1371/journal.pone.0161621>. Accessed: Jun. 15, 2019. doi: 10.1371/journal.pone.0161621.

MOLENTO, M. B. et al.. Bovine fascioliasis in Brazil: economic impact and forecasting. Vet Parasitol Reg Stud Rep, v.12: p.1-3, 2018. Available from: <https://pubmed.ncbi.nlm.nih. gov/31014798/>. Accessed: Jun. 15, 2020. doi: 10.1016/j. vprsr.2017.12.004.

MUKAKA, M. M. Statistics corner: A guide to appropriate use of correlation coefficient in medical research. Malawi Med J. v.24, n.3. p.69-71. 2012. PMID: 23638278. Available from: $<$ https:// pubmed.ncbi.nlm.nih.gov/23638278/>. Accessed: Jun. 15, 2020.

MULLER, R. The trematodes: Family Fasciolidae. In: Worms and human desease. 2.ed. London, UK: CABI Publishing. p. $46-49.2002$.

OLIVEIRA, S. M., ESPÓSITO FILHA, E. Divulgação Técnica: Fasciolose hepática. Biológico, v.71, n.1. p.5-7. 2009. Available from: <http://www.biologico.sp.gov.br/uploads/docs/bio/v71_1/ oliveira1.pdf $>$. Accessed: May, 05, 2018.

ROBINSON, M. W., DALTON, J. P. Zoonotic helminth infections with particular emphasis on fasciolosis and other trematodiases. Philos. Trans. R. Soc. Lond. B. Biol. Sci. (364). p.2763-2776. 2009. Available from: <https://pubmed.ncbi.nlm.nih.gov/19687044/>. Accessed: May, 05, 2018. doi: 10.1098/rstb.2009.0089.

SELEMETAS, N. et al. Spatial analysis and risk mapping of Fasciola hepatica infection in dairy herds in Ireland. Geospatial Health. v.9, n.2. p.281-291. 2015. Available from: <https:// geospatialhealth.net/index.php/gh/article/view/350>. Accessed: Mar. 15, 2018. doi: 10.4081/gh.2015.350.

SHAPIRO, S. S., WILK, M. B. "An Analysis of Variance Test for Normality (Complete Samples).” Biometrika, v.52, n.3/4, p.591-611. 1965 JSTOR. Available from: <https://www.jstor.org/ stable/2333709. >. Accessed: Oct. 20, 2020. doi: 10.2307/2333709.

SIEVERT, C. 2018. Interactive Web-Based Data Visualization with R, plotly, and shiny. Available from: <https:// plotly-book.cpsievert.me>. Accessed: Oct. 20, 2020. doi: $10.1201 / 9780429447273$.

SILVA, A. E. P. et al. 2020. Correlation between climate data and land altitude for Fasciola hepatica infection in cattle in Santa Catarina, Brazil. Braz J Vet Parasitol, v.29, n.3: e008520. Available from: $<\mathrm{https://www.}$ scielo.br/j/rbpv/a/rV8KQhmWzrXkMhKjxpm6vLp/abstract/?lang=en>. Accessed: Jun. 10, 2020. doi: 10.1590/S1984-29612020065.

ZAR, J. H. 2014. Spearman rank Correlation: Overview. In Wiley StatsRef: Statistics Reference Online (eds COLTON, N.B.T., PIEGORSCH, B.E.W.P., RUGGERI, F., TEUGLES, J.L.). Available from: <https://onlinelibrary.wiley.com/doi/ abs/10.1002/9781118445112.stat05964>. Accessed: Oct. 20, 2020. doi: 10.1002/9781118445112.stat05964. 